\title{
AIR POLLUTION IN THE VAAL TRIANGLE - QUANTIFYING SOURCE CONTRIBUTIONS AND IDENTIFYING COST-EFFECTIVE SOLUTIONS
}

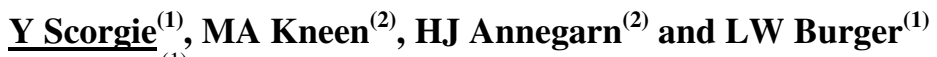 \\ ${ }^{(1)}$ Airshed Planning Professionals (Pty) Ltd \\ ${ }^{(2)}$ Atmosphere \& Energy Research Group, University of the Witwatersrand
}

\section{INTRODUCTION}

Encompassing a mixture of industrial, mining, commercial, agricultural and residential land use activities in close proximity to one another, the Vaal Triangle faces complex and pressing air pollution challenges. A wide range of air pollution and human health assessment studies were undertaken for the region during the 1990s with several additional studies being currently underway. Past studies indicated the occurrence of elevated particulate, sulphur dioxide, ozone, hydrogen sulphide and benzene concentrations and noted the potential which exists for high localised exposures to various hazardous air pollutants. Significant health impacts have been identified as occurring in the region due to the high airborne particulate concentrations.

The work undertaken to date has been important in terms of highlighting certain pollutants, areas and sources of concern in the Vaal Triangle. Despite this work a number of questions regarding the sources, impacts and costs of air pollution persist. The individual contribution of industrial, mining, residential, agricultural and transportation sectors to total atmospheric emissions, ambient air pollution concentrations and related impacts on human health and wellbeing remains the subject of debate and conjecture. Furthermore, questions are increasingly being asked regarding the contribution of atmospheric emissions being transported into the region from sources outside of the Vaal Triangle (e.g. residential coal burning within the Joburg). Given the proposal of more stringent national ambient air quality limits and the potential that exists for widespread noncompliance with such limits within the Vaal Triangle, emphasis is currently being placed on the identification of cost-effective emission reduction opportunities able to achieve the greatest human health risk reductions

Recent research has been undertaken to consolidate the results of past studies (Scorgie, 2003). Research aimed at quantifying the contribution of fuel-burning within various sectors to human health impacts and the costs associated with such impacts is also currently underway (Scorgie et al., 2003a; 2003b). The purpose of the latter study, which is being undertaken on behalf of NEDLAC, is to identify and quantify the benefits of effective interventions which target specifically fuelburning activities.

More detailed work has also been undertaken in parallel to the above mentioned studies with the purpose of providing constructive guidance to regulators tasked with air quality management and planning for the Vaal Triangle. In this health risk characterisation and costing study a damage function approach was adopted. This systematic approach links emissions and resource impacts related to an activity to changes in environmental quality, in this case air quality. Key sources of atmospheric emission were identified and quantified on the basis of available source and emissions data and emission calculations. Air quality impacts associated with sources inventoried were determined through the application of atmospheric dispersion modelling. The potential for and extent of health impacts arising due to fuel combustion related air emissions was subsequently established through the application of dose-response relationships.

The purpose of this paper is to present preliminary findings pertaining to the following:

- the percentage contribution of specific source sectors to total regional emissions of select criteria pollutants (viz. sulphur dioxide, particulate matter and oxides of nitrogen);

- predicted sectoral contributions to ambient concentrations of $\mathrm{SO}_{2}, \mathrm{PM} 10$ and $\mathrm{NO}_{\mathrm{x}}$;

- extent of particulate concentrations predicted to be imported into the region as a result of sources of atmospheric emission located outside of the Vaal Triangle;

- proportion of human health risks, including premature mortality, respiratory hospital admissions and chronic bronchitis, associated with ambient $\mathrm{SO}_{2}, \mathrm{PM} 10$ and $\mathrm{NO}_{\mathrm{x}}$ concentrations occurring due to specific source sectors; and

- development of a method for costing health impacts and preliminary health costs estimated to be associated with $\mathrm{SO}_{2}, \mathrm{PM} 10$ and $\mathrm{NO}_{\mathrm{x}}$ exposures in the Vaal Triangle. 
Given that no comprehensive and current emissions inventory exists for the Vaal Triangle it was necessary to limit the number of pollutants considered. $\mathrm{SO}_{2}$, PM10 and $\mathrm{NO}_{\mathrm{x}}$ were selected for the following reasons: (i) these pollutants have been noted to be elevated over the region, with exceedances of ambient air quality limits for $\mathrm{SO}_{2}$ and PM10 occurring relatively frequently, (ii) $\mathrm{SO}_{2}, \mathrm{PM} 10$ and $\mathrm{NO}_{\mathrm{x}}$ emissions are widespread, being associated with industrial and mining activities, domestic fuel burning, vehicle activity, biomass burning and power generation; and (iii) these pollutant act on the respiratory system, with respiratory health effects known to be of concern in the region.

Although the importance of assessing ozone and benzene concentrations was noted, given that high levels of these pollutant have been observed to occur in certain parts of the Vaal Triangle, these pollutants were not quantified as part of the study. The effective simulation of spatial and temporal trends in ozone concentrations would require photochemical modelling to be undertaken. Due to the complexity and data intensity of photochemical modelling and limited time available for the study, such modelling was not undertaken. Benzene emissions arising due to vehicle emissions (exhaust and evaporative) and due to domestic, industrial, commercial and institutional fuel burning activities were quantified as part of the NEDLAC study (Scorgie et al., 2003a). Due to these emissions data not yet been release for publication, and given the absence of emissions data from other sources, specifically evaporative releases from industrial operations and filling stations, it was decided not to include the benzene in the initial phase of the Vaal Triangle risk characterisation study.

Contributions to regional emissions, ambient air pollutant concentrations and health risks were quantified for four main source groupings, viz. (i) industrial, commercial and institutional activities, including industrial process emissions and releases from commercial and institutional fuel burning; (ii) residential sector, specifically emissions related to fuel combustion including wood, coal, LPG and paraffin combustion; (iii) vehicle exhaust emissions; and (iv) public electricity generation. Although the extent of emissions from biomass burning (veld burning) was quantified, predicted air pollutant concentrations due to such burning were found to be unrepresentative. This is likely to be due to the difficulty in modelling such emissions accurately. Due to their episodic nature and unpredictable duration biomass burning could not be adequately modelled using the dispersion modelling methodology adopted for the study. It was therefore decided not to use the results generated for the purpose of informing the decision making process.

\section{METHOD OF QUANTIFYING COSTING IMPACTS}

The following steps were undertaken as part of the Vaal Triangle health risk characterisation and costing study:

- identification and quantification of key sources of emission

- simulation of ambient air pollutant concentrations occurring due to emissions

- quantification of potential exposures and prediction of health risks

- monetary costing of health risks

- ranking of sources based on their health risk impacts

The methodological approach adopted for the quantification and costing of health impacts associated with inhalation exposures to $\mathrm{SO}_{2}, \mathrm{PM} 10$ and $\mathrm{NO}_{\mathrm{x}}$ concentrations is outlined in subsections below. The findings of the above steps would support the quantification of health cost reductions due to the implementation of select interventions, and the assessment of the potential for offsetting the costs of implementation with health cost savings.

\subsection{Emissions Inventory Compilation}

Sources of atmospheric emission in the Vaal Triangle include: Industrial and commercial activities including Scheduled Processes and non-domestic fuel burning appliance operation by businesses, hospitals and schools; (ii) waste treatment and disposal - waste incineration, landfills and waste water treatment works; (iii) residential - household combustion of coal, paraffin, LPG and wood, (iv) transport - petrol and diesel driven vehicle tailpipe emissions, vehicle entrained road dust, brake and tyre wear fugitives, and rail- and aviation-related emissions; (v) mining including fugitive dust releases and spontaneous combustion emissions; and (vi) informal / miscellaneous - tyre burning, wild fires and fugitive dust emissions from open areas and agricultural activities Emphasis was placed on the collation of information and assessment of emissions from the following sources located within the Vaal Triangle:

- industrial operations, mines and power stations

- domestic fuel burning

- vehicle emissions - including exhaust and entrainment emissions

- biomass burning (veld fires) 


\subsubsection{Industrial and Power Generation Emissions}

In the collation of source and emissions data for the industrial and power generation sector reference was made to secondary sources of information. Such sources included authorities tasked with air pollution control in the region, the national source inventory data base last updated in 1994, previously undertaken studies (van Nierop, 1995) and published emission figures in the annual environmental reports of certain companies (Sasol, Eskom). Use was only made of source and emissions data which where either in the public domain or for which permission had been obtained.

\subsubsection{Domestic Fuel Burning Emissions}

The continued use of coal and wood by a large section of the population within the Vaal Triangle represents a cause for concern with regard to air pollution and health risk potentials. Fuel burning areas include Boipatong, Bophelong, Evaton, Orange Farm, Sebokeng, Sharpville and Zamdela. These fuels continue to be used for primarily two reasons: (i) rapid urbanisation and the growth of informal settlements has exacerbated backlogs in the distribution of basic services such as electricity and waste removal, and (ii) various electrified households continue to use coal due particularly to its cost effectiveness for space heating purposes and its multi-functional nature (supports cooking, heating and lighting functions). Coal is relatively inexpensive and is easily accessible due to the proximity of the region to coal mines and the welldeveloped local coal merchant industry.

The estimation of domestic fuel burning emissions is challenging given that the amount of fuel being consumed is not known with certainty. The average coal usage per household varies depending on:

- type of house (formal house, planned shack, unplanned shack or backyard shack)

- whether or not a household is electrified

- the number of people living in the house

- the season

- the availability of coal

- the price of coal and the household income

Making reference to The South African Policy Research and Training Project undertaken by the Energy for Development Research Centre (1993), van Nierop noted that approximately $45 \%$ of electrified 'township' households and $88 \%$ of unelectrified 'township' household use coal on a daily basis for cooking and space heating. He estimated that $\sim 145$
000 tons of coal was being burned in the main 'townships' within the Vaal Triangle. Emission factors were varied for different house types: 10 grams particulates per $\mathrm{kg}$ of coal for formal houses, $15 \mathrm{~g} / \mathrm{kg}$ for planned and unplanned shacks and $30 \mathrm{~g} / \mathrm{kg}$ for backyard shacks. Van Nierop also obtained estimates of the combustion of other fuels (wood, anthracite, LPG, paraffin) in the region and calculated particulate emissions associated with such fuels. Total domestic fuel burning emissions were given as being $2521 \mathrm{tpa}$ TSP and 1260 tpa PM10.

In the current study reference was made to more recent data to assess whether van Nierop's results are still valid and to facilitate the estimation of emissions from pollutants other than particulates. Such data included:

- energy use information from the 1996 Census

- emission factors established by the AEC for coal burning in stoves and braziers (Britton, 1998)

- a recent reassessment of the amount of coal burned per household by Qase et al. (2000).

Qase et al. (2000) reassessed the amount of coal burning within households by surveying coal sales by local mines, obtaining sales data from coal merchants and inventorying coal usage by individual households. The main conclusion of this study was that the average household consumes about $50 \mathrm{~kg}$ of coal per week during cold periods ( $\sim 10$ weeks a year) and less than $20 \mathrm{~kg}$ per week in summer, resulting in an estimated one ton of coal being used per annum in total per household. Van Nierop calculated an average household coal consumption figure of $\sim 1.38$ tpa.

According to the 1996 census data, as obtained from Central Statistics Services, the population of the Vaal Triangle is in the order of 928000 people, comprising 236000 households, $66.5 \%$ of which are electrified. Based on information from the 1996 census, $21.8 \%$ of households (51427 household) still use coal and 4.3\% of households (10054 households) continue to use wood. Although it appears from the Census data that the number of households consuming coal has significantly decreased, given van Nierop's estimate of 105 300 households burning coal, it is noted that the Census is likely to underestimate coal use. The reason for this is twofold: (i) census data is more readily obtained from formal households which are less likely to burn coal if compared to informal houses, and (ii) information is typically collected on one fuel use per energy requirement whereas many households use a range of 2 to 5 fuels to meet their energy needs. 
Should it be assumed that $45 \%$ of electrified 'township' households and $88 \%$ of unelectrified 'township' households use coal, the estimate of households burning coal - based on the 1996 Census data on electrification - would be in the order of 140 200 households. Using the information provided by Qase et al. (2000) on household coal use, it could be estimated that 140200 tons of coal are being combusted. This is within a similar range to the coal use estimate of van Nierop (145 146 tpa).

A comprehensive set of emission factors for domestic coal burning has been established in South Africa to support the estimation of emissions of a wide range of pollutants including criteria pollutants such as PM10 and various VOCs and semi-VOCs. This set of emission factors was determined by the Atomic Energy Corporation of South Africa Limited (AEC) for low-grade coal and ten low-smoke fuels (Britton, 1998). This work was commissioned by the Department of Minerals and Energy as part of the lowsmoke fuel programme. Emission factors were generated in terms of grams of pollutant per MJ. The calorific value of "normal coal" was determined by the AEC as $27.4 \mathrm{MJ} / \mathrm{kg}$. The particulate emission rate for the refueling stage of a fire was estimated to be $\sim 8.1$ $\mathrm{g} / \mathrm{kg}$ coal for braziers - this coincides with emission factors developed by other researchers for 'low smoke stoves' (Rogers, 1995; Rogers and Pieters, 1994). Van Nierop's approach was therefore conservative with his having made reference to emission factors in the range of $10 \mathrm{~g} / \mathrm{kg}$ to $15 \mathrm{~g} / \mathrm{kg}$. Given the AEC and CSIR emissions monitoring campaigns (as documented by Britton and Rogers respectively) were conducted under laboratory conditions and may not be completely representative of emissions in the field, van Nierop's higher emission rate figures seem appropriate.

Reference was made to US-EPA emission factors for residential fire places (EPA, 2000) and to the AEC's emission factors (Britton, 1998) to estimate gaseous emissions from domestic fuel burning.

\subsubsection{Vehicle Emissions}

In the estimation of petrol-driven vehicle emissions the vehicle fleet was characterised, the rate of implementation of new vehicle technologies evaluated, and vehicle kilometres travelled estimated on the basis of petrol sales data. The petrol-driven vehicle fleets were characterised based on the 1992 technology mix and the 1995 engine capacity profiles collated for the Vehicles Emission Project (Terblanche, 1995). Information is given in Terblanche (1995) for Cape Town, Johannesburg, Durban, the Vaal Triangle and
Pretoria. A current national vehicle population data base was obtained from Stellenbosch Automotive Engineering to supplement the spatially-resolved 1992 technology mix and 1995 engine capacity data obtained from Terblanche (1995). The national vehicle parc data, obtained by Stellenbosch Automotive Engineering for use in the recent Octane Study, comprises detailed information on petrol-driven vehicles sold between 1970 and 2002 including: engine capacity, need for lead replacement petrol, presence of fuel injection and catalytic converters (etc.). The current national data provided valuable information on the percentage of vehicles within the current live population which are fitted with catalytic converters $(7.3 \%)$ and on the growth rate of catalytic converter use in new vehicles $(47.3 \%$ of new cars purchased in 2002 were equipped with catalytic converters, with an annual average growth rate of $3.9 \%$ noted based on the $1990-2002$ period).

Annual leaded and unleaded petrol sales data, obtained from the South African Petroleum Industries Association (SAPIA) per magisterial district for 2001, were used to estimate the total vehicle kilometres travelled using fuel consumption rates suited to each engine capacity class and general fuel type. (Petrol consumption rates range from 7.7 to 15.1 litres per 100 km) (Wong, 1999). Locally developed emission factors published by Wong (1999) were applied taking into account variations in such factors for different energy capacities and altitudes (coastal, highveld factors). Emissions were calculated by multiplying the emission factors by the total vehicle kilometres travelled (VKT) estimated on the basis of the 2001 fuel sales data.

In the estimation of diesel-driven vehicle emissions average percentages of light commercial vehicles (LCVs) and medium and heavy commercial vehicles (M\&HCVs) within the national diesel vehicle fleet were obtained from Stone (2000). Diesel consumption rates were obtained for $\mathrm{LCVs}$, MCVs and $\mathrm{HCVs}$ for coastal and highveld applications from Stone (2000) and Wong (1999). Such rates varied from 10.5 to 24.4 litres per $100 \mathrm{~km}$. Annual diesel sales data, obtained from SAPIA per magisterial district for 2001, were used to estimate the total vehicle kilometres travelled using fuel consumption rates suited to each vehicle weight category. Locally developed emission factors published by Stone (2000) were applied taking into account variations in vehicle weight categories and altitudes (coastal, highveld factors). As for the petroldriven vehicles, emissions were calculated by multiplying the emission factors by the total vehicle 
kilometres travelled (VKT) estimated on the basis of the 2001 fuel (diesel) sales data.

\subsubsection{Biomass Burning Emissions}

In order to estimate the extent of biomass burning it was necessary to quantify the average area burned. Satellite imagery was obtained to identify and quantify burn scar areas. Burn scar images generated included 5-year composite scar plots (1995-2000) and plots indicating the extent of areas burned during a single fire season. In the Vaal Triangle it was estimated that the area to have been burnt during the 1995-2000 period was in the order of $25 \%$ of the total area. Emission factors derived during SARAFI-2000 (Southern African Fire-Atmosphere Research Initiative), as published by Andreae et al. (1996), were applied in the estimation of atmospheric emissions from veld fires.

\subsection{Simulation of Ambient Air Pollutant Concentrations}

The simulation of ambient pollutant concentrations due to inventoried sources was undertaken through the application of the United States Environmental Protection Agency (US-EPA) approved Industrial Source Complex Short Term (version 3) model (EPA, 1995). The ISCST3 model is a Gaussian plume model suited to the simulation of emissions from point, area and volume sources located in relatively simple terrain environments. The ISC model typically produces predictions within a factor of 2 to 10 within complex topography with a high incidence of calm wind conditions. When applied in flat or gently rolling terrain, the USA-EPA (EPA, 1986) considers the range of uncertainty of the ISC to be $-50 \%$ to $200 \%$.

The modelling domain comprised an area of $1352 \mathrm{~km}^{2}$ $(29.3 \mathrm{~km}$ east-west by $46.15 \mathrm{~km}$ north-south) with a grid resolution of $\sim 1.1 \mathrm{~km}$. Hourly average meteorological data from the South African Weather Services' Vereeniging station were used as input in the modelling.

During the compilation of the emissions inventory total annual emissions were calculated/collated. In the simulation of such emissions it was crucial to take into account temporal variations in the emissions of certain sources such as domestic fuel burning and vehicle emissions. Seasonal trends in domestic fuel combustion for space heating purposes were characterised through the calculation of the number of "heating-degree-days" (i.e. number of days on which the minimum daily temperature falls below $8^{\circ} \mathrm{C}$ resulting in the need for space heating). Diurnal trends in space heating related fuel combustion were characterised based on time-series analysis of aerosol black carbon (BC) concentrations as a tracer of domestic coal burning emissions (Annegarn and Grant, 2000). Diurnal trends were also estimated for household fuel burning undertaken for lighting, cooking and water heating purposes.

Seasonal trends in vehicle activity, and hence emissions, are not clearly apparent (except for a slight reduction in vehicle activity in certain areas during the month of December). Distinctive diurnal trends in vehicle activity are however apparent. Diurnal profiles were applied in order to calculate hourly emissions from vehicles. Approximately $80 \%$ of vehicle activity typically takes place during the day-time with a sharp morning and more sustained afternoon peak in activity apparent on major feed routes.

Emissions due to power generation and industrial and commercial fuel combustion were assumed to remain constant throughout the year.

\subsection{Health Effect Estimation through Dose- Response Function Application}

Dose-response relationships provide the link between exposures to ambient air pollutant concentrations and the resultant health outcomes. Given the absence of locally generated relationships it is necessary to make reference to the international literature to identify dose-response functions which are applicable to South Africa. The dose-response functions used in the study are given in Table 1. Such factors are applied by multiplying the exposure (i.e. population * pollutant concentration) with the function to obtain an indication of impact. Impacts are expressed as the number of hospital admissions due to respiratory ailments and cardiovascular related symptoms, number of premature deaths, (etc.). 
Table 1: Dose-response functions used to quantify inhalation exposures to air pollutant concentrations in the Vaal Triangle

\begin{tabular}{|c|c|c|c|c|}
\hline HEALTH ENDPOINT & $\begin{array}{c}\text { POLLUTA } \\
\text { NT }\end{array}$ & $\begin{array}{c}\text { POP } \\
\text { SECTOR }\end{array}$ & FUNCTION & SOURCE \\
\hline $\begin{array}{l}\text { Respiratory hospital } \\
\text { admissions - daily } \\
\text { exposures }\end{array}$ & PM10 & All persons & $1.20 \times 10^{-5}$ & $\begin{array}{l}\text { Ostro } 1994 \text { as referenced in } \\
\text { World Bank } 1998\end{array}$ \\
\hline $\begin{array}{l}\text { Respiratory hospital } \\
\text { admissions - daily } \\
\text { exposures }\end{array}$ & $\mathrm{SO}_{2}$ & All persons & $2.01 \times 10^{-6}$ & $\begin{array}{l}\text { Maddison } 1997 \text { as referenced } \\
\text { in WB } 1998\end{array}$ \\
\hline $\begin{array}{l}\text { Respiratory hospital } \\
\text { admissions - daily } \\
\text { exposures }\end{array}$ & $\mathrm{NO}_{2}$ & All persons & $1.65 \times 10^{-6}$ & $\begin{array}{l}\text { Maddison } 1997 \text { as referenced } \\
\text { in WB } 1998\end{array}$ \\
\hline $\begin{array}{l}\text { Cardiovascular hospital } \\
\text { admission - daily exposures }\end{array}$ & PM10 & All persons & $1.01 \times 10^{-7}$ & Dockery et al. 1993 \\
\hline $\begin{array}{l}\text { Daily Mortality - daily } \\
\text { exposures }\end{array}$ & PM10 & $>=65$ years & $4.42 \times 10^{-7}$ & $\begin{array}{l}\text { EXMOD - as referenced by } \\
\text { Nelson } 2000\end{array}$ \\
\hline $\begin{array}{l}\text { Daily Mortality - daily } \\
\text { exposures }\end{array}$ & PM10 & $<65$ years & $2.35 \times 10^{-8}$ & $\begin{array}{l}\text { EXMOD - as referenced by } \\
\text { Nelson } 2000\end{array}$ \\
\hline $\begin{array}{l}\text { Daily Mortality - daily } \\
\text { exposures }\end{array}$ & $\mathrm{SO}_{2}$ & $>=65$ years & $1.01 \times 10^{-8}$ & Holland and Watkiss 2002 \\
\hline $\begin{array}{l}\text { Daily Mortality - daily } \\
\text { exposures }\end{array}$ & $\mathrm{SO}_{2}$ & $<65$ years & $1.38 \times 10^{-9}$ & Holland and Watkiss 2002 \\
\hline $\begin{array}{l}\text { Chronic Bronchitis - annual } \\
\text { exposures }\end{array}$ & PM10 & $\begin{array}{c}\text { children }(<5 \\
\text { years })\end{array}$ & $1.61 \times 10^{-3}$ & Dockery et al. 1993 \\
\hline $\begin{array}{l}\text { Chronic Bronchitis - annual } \\
\text { exposures }\end{array}$ & PM10 & $\begin{array}{c}\text { adults }(20 \\
\text { years }+)\end{array}$ & $4.90 \times 10^{-5}$ & Abbey et al. 1995 \\
\hline $\begin{array}{l}\text { Restricted activity days } \\
\text { (RAD) -daily exposures }\end{array}$ & PM10 & 20-65 years & $1.60 \times 10^{-4}$ & $\begin{array}{l}\text { Rowe et al. } 1994 \text { as } \\
\text { referenced in van Horen } 1996\end{array}$ \\
\hline
\end{tabular}

\subsection{Costing of Health Effects}

Costs associated with inhalation exposures to air pollution include direct and indirect costs. Direct costs are associated with health spending, e.g. cost of hospital admissions and medication. Indirect costs include financial losses due to reduced productivity resulting from the restricted activity of economically active persons. For the purpose of informing health risk costing studies costs related to respiratory illnesses such as asthma and chronic bronchitis were obtained from Medscheme. Information obtained included the ratio of inpatients to outpatients and public and private costs of treatment for both inpatients and outpatients.

\section{ESTIMATED SOURCE CONTRIBUTIONS}

Sources may be ranked on the basis of various criteria, including: (i) contribution to total emissions, (ii) contribution to ambient air pollutant concentrations, and (iii) contribution to health impacts. The latter represents the most effective criteria for source significance rating given that it takes into account the extent of emissions, the source configuration (e.g. height of release) and the proximity of the source to sensitive receptors where exposure and hence impacts are likely. Source contributions to total emissions, ambient air pollutant concentrations and health impacts are presented in this section with emphasis being placed on the latter as the basis for selecting cost-effective interventions.

\subsection{Source Contributions to Total Emissions}

Total annual PM10, $\mathrm{SO}_{2}$ and $\mathrm{NO}_{\mathrm{x}}$ emission estimates for the various source groupings are presented in Table 2 . From the table it is evident that industrial and mining operations and electricity generation is estimated to be responsible for over $90 \%$ of the $\mathrm{PM} 10, \mathrm{SO}_{2}$ and $\mathrm{NO}_{\mathrm{x}}$ emissions. The impacts of sources are however 
dependent not only on the type of pollutant released and the extent of emissions but also on the location of such sources to sensitive receptors (e.g. residential areas, sensitive ecosystems, commercial crops).

The significance of industrial and power generation emissions in terms of their contributions to air pollutant concentrations and public health risks is frequently lower than would be expected given the extent of the emissions. This is due to these sources generally being characterised by constant, high level releases with such emissions also likely to be more remote from residential settlement compared to household fuel burning and vehicle emissions.

The significance of domestic fuel burning emissions is enhanced due to three factors: (i) the low level of emissions, (ii) the coincidence of peak emissions, typically a factor of 10 greater than if total annual emissions were averaged, with periods of poor atmospheric dispersion (i.e. night-time, winter-time), and (iii) the release of such emissions within high human exposure areas with high contributions to both indoor and outdoor pollution concentrations. The significance of biomass burning is similarly enhanced as a localised source of episodic emissions due the low level of release and the fact that emissions are concentrated during the burn season.

The significance of vehicle emissions in terms of the contribution to air pollutant concentrations and health risks is enhanced by the low level at which emissions occur and the proximity of such releases to high exposure areas. Vehicle emissions also tend to peak in the early morning and evenings at which time atmospheric dispersion potentials are reduced.

Table 2. Total annual emissions estimated for various source groups for the Vaal Triangle (the percentage contribution of each group to total emissions is given in brackets)

\begin{tabular}{|l|c|c|c|}
\hline \multirow{2}{*}{ Source Grouping } & \multicolumn{3}{|c|}{ Total Annual Emissions } \\
\cline { 2 - 4 } & PM10 (tpa) & $\mathbf{S O}_{\mathbf{2}}$ (tpa) & NO $_{\mathbf{x}}$ (tpa) \\
\hline Industry, commerce, & $34907(\mathrm{a})$ & $78804(\mathrm{~b})$ & $36294(\mathrm{~b})$ \\
mining & $(77.4 \%)$ & $(26.0 \%)$ & $(24.9 \%)$ \\
\hline Electricity generation & 8150 & 219868 & 98457 \\
& $(18.1 \%)$ & $(72.4 \%)$ & $(67.4 \%)$ \\
\hline Household fuel & 1260 & 2917 & 363 \\
burning & $(2.8 \%)$ & $(0.96 \%)$ & $(0.25 \%)$ \\
\hline Vehicle exhaust & 400 & 1904 & 10639 \\
& $(0.89 \%)$ & $(0.63 \%)$ & $(7.3 \%)$ \\
\hline Biomass burning & 392 & 47 & 243 \\
& $(0.87 \%)$ & $(0.02 \%)$ & $(0.17 \%)$ \\
\hline TOTAL & 45109 & 303540 & 145996 \\
\hline
\end{tabular}

(a) PM10 emission estimates include controlled stream and fugitive particulate emissions from over 70 industrial and mining operations, in addition to particulate emissions from $\sim 40$ institutional/commercial boiler operations (e.g. hotel, school, hospital boilers).

(b) Sulphur dioxide and nitrogen oxide emission estimates were only available for $\sim 25 \%$ of the industrial and mining operations for which particulate emissions data were obtained. In addition to which $\mathrm{SO}_{2}$ and $\mathrm{NO}_{\mathrm{x}}$ emissions were estimated for the $\sim 40$ institutional/commercial boiler operations. Although $\mathrm{SO}_{2}$ and $\mathrm{NO}_{\mathrm{x}}$ emissions were only available for $20 \%$ to $30 \%$ of industrial operations, emissions from all the largest sources were accounted for. It is therefore anticipated that a significant proportion (at least 70\%) of the $\mathrm{SO}_{2}$ and $\mathrm{NO}_{\mathrm{x}}$ emissions due to industrial operations are accounted for in the estimate. 


\subsection{Source Contributions to Ambient Air Pollutant Concentrations}

In the simulation of ambient air pollutant concentrations arising due to various sources, dispersion models facilitate the parameterisation of various factors related to the source which determine the extent and spatial and temporal variations in resultant pollutant concentrations. Such factors include the 'effective' release height (i.e. the actual stack height in addition to the plume rise due to the momentum and buoyancy of the plume), in addition to the extent and duration of emissions.

Air pollutant concentrations were simulated for various averaging periods in order to facilitate comparisons with monitoring results and ambient air quality limits, in addition to supporting the application of the various dose-response functions selected for health risk calculation. The current Department of Environmental Affairs and Tourism (DEAT) ambient air guidelines given for PM10 and sulphur dioxide are as follows: $180 \mu \mathrm{g} / \mathrm{m}^{3}$ for maximum daily PM10 concentrations; $60 \mu \mathrm{g} / \mathrm{m}^{3}$ for annual average PM10 concentrations; $125 \mu \mathrm{g} / \mathrm{m}^{3}$ for maximum daily average $\mathrm{SO}_{2}$ and $50 \mu \mathrm{g} / \mathrm{m}^{3}$ for annual average $\mathrm{SO}_{2}$. South Africa's air quality guidelines are currently being revised with more stringent limits being proposed for PM10 concentrations (i.e. $75 \mu \mathrm{g} / \mathrm{m}^{3}$ for daily maximums and $40 \mu \mathrm{g} / \mathrm{m}^{3}$ for annual averages).

Exceedances of current PM10 and $\mathrm{SO}_{2}$ guidelines (and significant exceedances of the proposed PM10 limits) have been measured to occur in the Vaal Triangle. Predicted PM10 concentrations were found to be similar to PM10 levels recorded in the region over the past decade (1994 to 2003). Monitoring undertaken includes recent ambient monitoring conducted by Sasol, New Vaal Colliery and Iscor Vanderbijlpark Works in addition to monitoring undertaken by Mintek in Vereeniging, Sasolburg and Vanderbijlpark during the $1994-5$ period. In non-fuel burning residential areas average annual PM10 concentrations were typically found to range from 60 to $70 \mu \mathrm{g} / \mathrm{m}^{3}$ with maximum daily PM10 concentrations in the order of 150 to $220 \mu \mathrm{g} / \mathrm{m}^{3}$. Maximum daily PM10 levels were observed to be in the range of 200 to $300 \mu \mathrm{g} / \mathrm{m}^{3}$ in heavy industrial, intensive mining and household fuel burning areas, with annual average concentrations of 80 to $100 \mu \mathrm{g} / \mathrm{m}^{3}$ evident. Maximum hourly average sulphur dioxide concentrations of between 1200 and $1500 \mu \mathrm{g} / \mathrm{m}^{3}$ have been recorded to occur in heavy industrial areas in Vanderbijlpark and Sasolburg and within neighbouring residential areas in Sasolburg. Maximum daily average concentrations in the range of
180 to $850 \mu \mathrm{g} / \mathrm{m}^{3}$ and annual average concentrations of 40 to $80 \mu \mathrm{g} / \mathrm{m}^{3}$ have been recorded in these areas.

Predicted maximum daily and annual average PM10, $\mathrm{SO}_{2}$ and $\mathrm{NO}_{\mathrm{x}}$ concentrations were comparable to measured concentrations. Current PM10 guidelines were predicted to be exceeded within all domestic fuel burning, heavy industrial and large-scale mining areas. Maximum frequencies of exceedance of the current DEAT PM10 daily guideline of $180 \mu \mathrm{g} / \mathrm{m}^{3}$ was predicted to occur in the Vanderbijlpark industrial area and at Zamdela ( $30 \%$ of days exceeding guideline). The proposed PM10 daily maximum guideline of 75 $\mu \mathrm{g} / \mathrm{m}^{3}$ was predicted to be exceeded over the entire Vaal Triangle, with maximum frequencies of exceedance being in the order of $\sim 80 \%$ of days. Daily maximum $\mathrm{SO}_{2}$ concentrations were predicted to exceed the DEAT daily guideline in most areas in the Vaal Triangle with the exception of Meyerton. The annual $\mathrm{SO}_{2}$ guideline was only predicted to be exceeded in certain domestic coal burning areas and within parts of Sasolburg in relative close proximity to the adjacent industrial area.

An attempt was made to evaluate transboundary source contributions to annual average PM10 concentrations occurring within the Vaal Triangle. The quantification of transboundary sources was however limited to emissions from domestic, agricultural, road vehicle, industrial and power generation fuel combustion within the Tshwane, Joburg, Ekurhuleni and Mpumalanga Highveld areas. Elevated industrial process emissions and biomass burning within areas north of Tshwane, which are also known to contribute to background particulate concentrations in the Vaal Triangle, were not quantified.

Source contributions to annual average PM10 concentrations predicted for various locations are illustrated in Figure 1. The locations at which the source apportionment predictions were output are illustrated in Figure 2. From Figure 2 it is evident that the source contributions were undertaken for a single point within the CBDs (Vanderbijlpark, Vereeniging, Sasolburg, Meyerton) and within the centre of select fuel burning residential areas (Sebokeng, Sharpville). The contribution of domestic fuel burning emissions to ambient annual PM10 concentrations was predicted to be distinctly different at Sebokeng and Sharpville. Whereas domestic fuel burning was estimated to be responsible for $84 \%$ of the annual PM10 concentrations at Sebokeng, the contribution at Sharpville was only in the order of $45 \%$ due to the location of Sharpville in close proximity and downwind of the Vanderbijlpark industrial areas. 
Emissions from the industrial, commercial and mining source grouping was predicted to be the largest contributor to annual average PM10 concentrations at most of the sites. Excluding Sebokeng, this groupings contribution ranged from $50 \%$ at Sharpville to $88 \%$ in
Meyerton. Despite the significant emissions from power generation, the contribution of such emissions to ground level ambient annual PM10 concentrations at the points noted was estimated to be below $0.2 \%$.
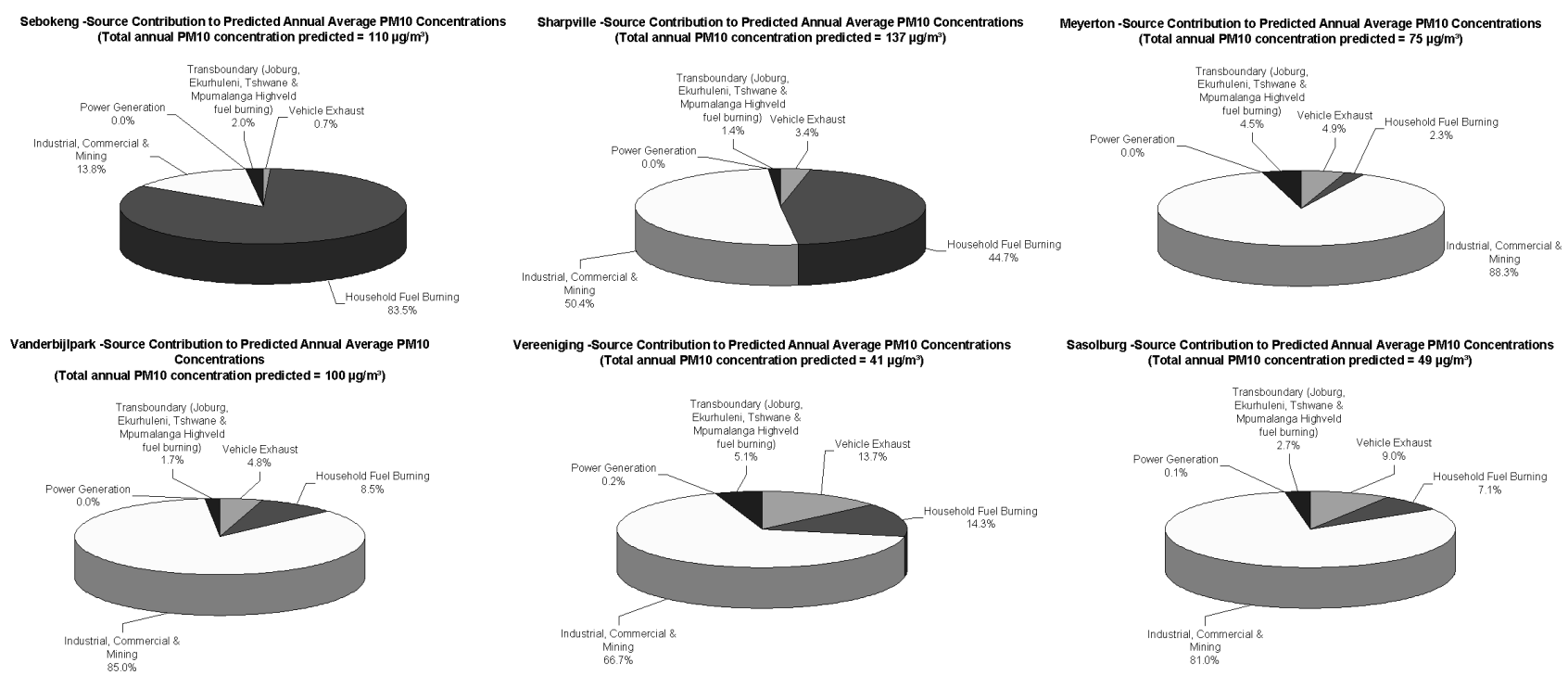

Figure 1. Predicted source contributions to total annual PM10 concentrations at various locations within the Vaal Triangle (locations illustrated in Figure 2). Results are given for a central point within the CBDs of various areas (Sasolburg, Meyerton, Vereeniging, Vanderbijlpark) and for a central point in select fuel burning residential areas (Sebokeng, Sharpville)

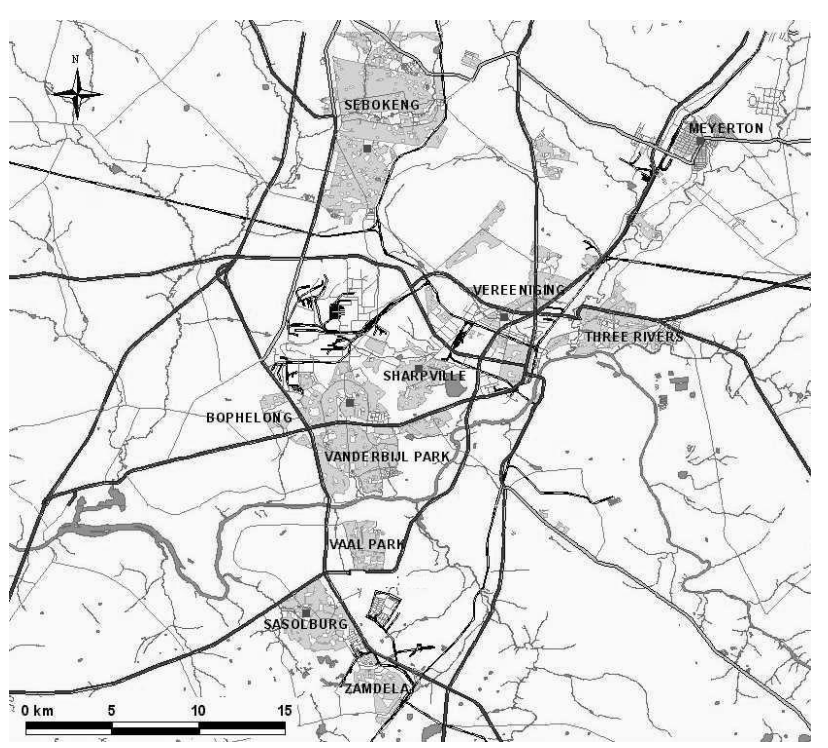

Figure 2. Location of sites at which source contributions to predicted total annual PM10 concentrations are illustrated in Figure 1.

Vehicle exhaust contributions were predicted to be in the range of $0.7 \%$ to $14 \%$. The contribution of vehicle exhaust emissions to ambient PM10 concentrations should however be cautiously interpreted. For the purpose of the current study vehicle emissions were estimated on the basis of magisterial fuel sales data with such emissions having been spatially allocated on the basis of road densities. To gain an accurate representation of spatial variations in vehicle emission contributions one would need to use accurate, spatially and temporally resolved vehicle activity flow data in the emission estimation and dispersion simulations.

\subsection{Source Contributions to Human Health Risks and associated Costs}

In the quantification of health effects occurring due to inhalation exposures, predicted air pollutant concentrations were overlaid over spatial population data from the 2001 census. The census data makes it possible to distinguish between various age groups, with population statistics given in 5 year age intervals. A synopsis of the population figures for Vaal Triangle is given in Table 3 . 
Table 3. Summary of total persons within each population subsector of interest in the current study (based on information from the 2001 census, as obtained from Statistics South Africa)

\begin{tabular}{|l|c|}
\hline \multicolumn{1}{|c|}{ Population Sector } & Vaal Triangle \\
\hline Total Pop & $1,574,266$ \\
\hline Children $(<5$ years $)$ & 289,264 \\
\hline $20-65$ & 871,856 \\
\hline Adult $(>20$ years $)$ & 920,050 \\
\hline$<65$ years & 48,194 \\
\hline$>65$ years & 871,856 \\
\hline
\end{tabular}

For the purpose of the current study, it was necessary to assume that children were in the $<5$ year age group with the potentially economically active population assumed to be within the 20 to 65 year age group. Adults were defined as persons over 20 years of age. The predicted air pollutant concentration was taken to be equivalent to the dose, i.e. it was assumed that pollutant concentrations predicted for a particular location were being inhaled by the persons residing at that location.

Total respiratory hospital admissions, premature mortalities and restricted activity rates predicted to occur due to exposures to emissions from the various source groupings are presented in Table 4. Total respiratory hospital admissions were calculated to be in the order of $\sim 11600$. Assuming that persons are only admitted once each it would mean that up to $0.74 \$$ of the population could be affected. Cardiovascular hospital admissions of $~ 90$ per annum were estimated $(0.006 \%$ of population). Exposure to $\mathrm{PM} 10$ and $\mathrm{SO}_{2}$ concentrations were also found to be associated with $\sim 25$ premature deaths, with $0.002 \%$ of the population affected. Incidence of chronic bronchitis were estimated to be $\sim 24000$ with $1.54 \%$ of the population affected. A total of $\sim 78750$ restricted activity days was estimated, representing 9 days per annum per potentially economically active person (i.e. persons 20 to 65 years of age).

Source contributions to the various health endpoints quantified as occurring due to inhalation exposures to $\mathrm{PM} 10, \mathrm{SO}_{2}$ and $\mathrm{NO}_{\mathrm{x}}$ concentrations are illustrated in Figure 3. Domestic fuel combustion was found to result in the greatest risk, being responsible for $60 \%$ to $65 \%$ of the predicted respiratory hospital admissions, cardiovascular hospital admissions, premature mortality and restricted activity days. It is however notable that exposures related to domestic fuel burning was only estimated to account for $33 \%$ of the chronic bronchitis cases predicted to occur. The industrial, mining and institutional fuel burning source group was estimated to be responsible for $65 \%$ of the predicted chronic bronchitis cases due to emissions from this group being more constant throughout the year. (Chronic bronchitis estimates are based on exposures to annual average PM10 concentrations rather than to maximum daily concentrations). Industry, mining and institutional fuel burning was predicted to also account for $30 \%$ to $33 \%$ of the hospital admissions, restricted activity days and premature mortalities.

Power station emissions are estimated to account for $7.7 \%$ of the respiratory hospital admissions and $6.4 \%$ of the premature mortalities due primarily to its sulphur dioxide emissions. The contribution of power station emissions to chronic bronchitis cases and restricted activity days is lower due to these health endpoints being estimated based exclusively on PM10 concentration exposures. Vehicle exhaust emissions were estimated to account for $0.1 \%$ to $0.5 \%$ of the predicted health impacts. 
Table 4. Health impacts associated with human exposures to particulate, sulphur dioxide and nitrogen dioxide emissions from domestic fuel burning, vehicle exhausts, industrial and mining operations and electricity generation activities within the Vaal Triangle

\begin{tabular}{|l|r|r|r|r|r|}
\hline \multicolumn{1}{|c|}{ HEALTH ENDPOINT } & $\begin{array}{c}\text { DOMESTIC } \\
\text { FUEL } \\
\text { BURNING }\end{array}$ & $\begin{array}{l}\text { INDUSTRIAL, } \\
\text { COMMERCIAL } \\
\text { \& MINING }\end{array}$ & $\begin{array}{c}\text { VEHICLE } \\
\text { EXHAUST }\end{array}$ & $\begin{array}{l}\text { ELECTRICITY } \\
\text { GENERATION }\end{array}$ & TOTAL \\
\hline $\begin{array}{l}\text { Respiratory hospital admissions (due } \\
\text { to PM10, } \mathrm{SO}_{2} \text { and } \mathrm{NO}_{2} \text { exposures) }\end{array}$ & 7218.0 & 3422.7 & 62.7 & 892.7 & 11596.1 \\
\hline $\begin{array}{l}\text { Cardiovascular hospital admissions } \\
\text { (due to PM10 exposures) }\end{array}$ & 58.6 & 28.3 & 0.1 & 2.7 & 89.8 \\
\hline $\begin{array}{l}\text { Premature mortality (due to PM10 } \\
\text { and SO } \text { O }_{2} \text { exposures) }\end{array}$ & 15.5 & 8.3 & 0.0 & 1.6 \\
\hline $\begin{array}{l}\text { Chronic bronchitis (due to PM10 } \\
\text { exposures) }\end{array}$ & 8000.2 & 15759.3 & 35.4 & 25.4 \\
\hline $\begin{array}{l}\text { Restricted activity days (RAD, due to } \\
\text { PM10 exposures) }\end{array}$ & 51369.6 & 24745.0 & 134.2 & & 24159.8 \\
\hline
\end{tabular}

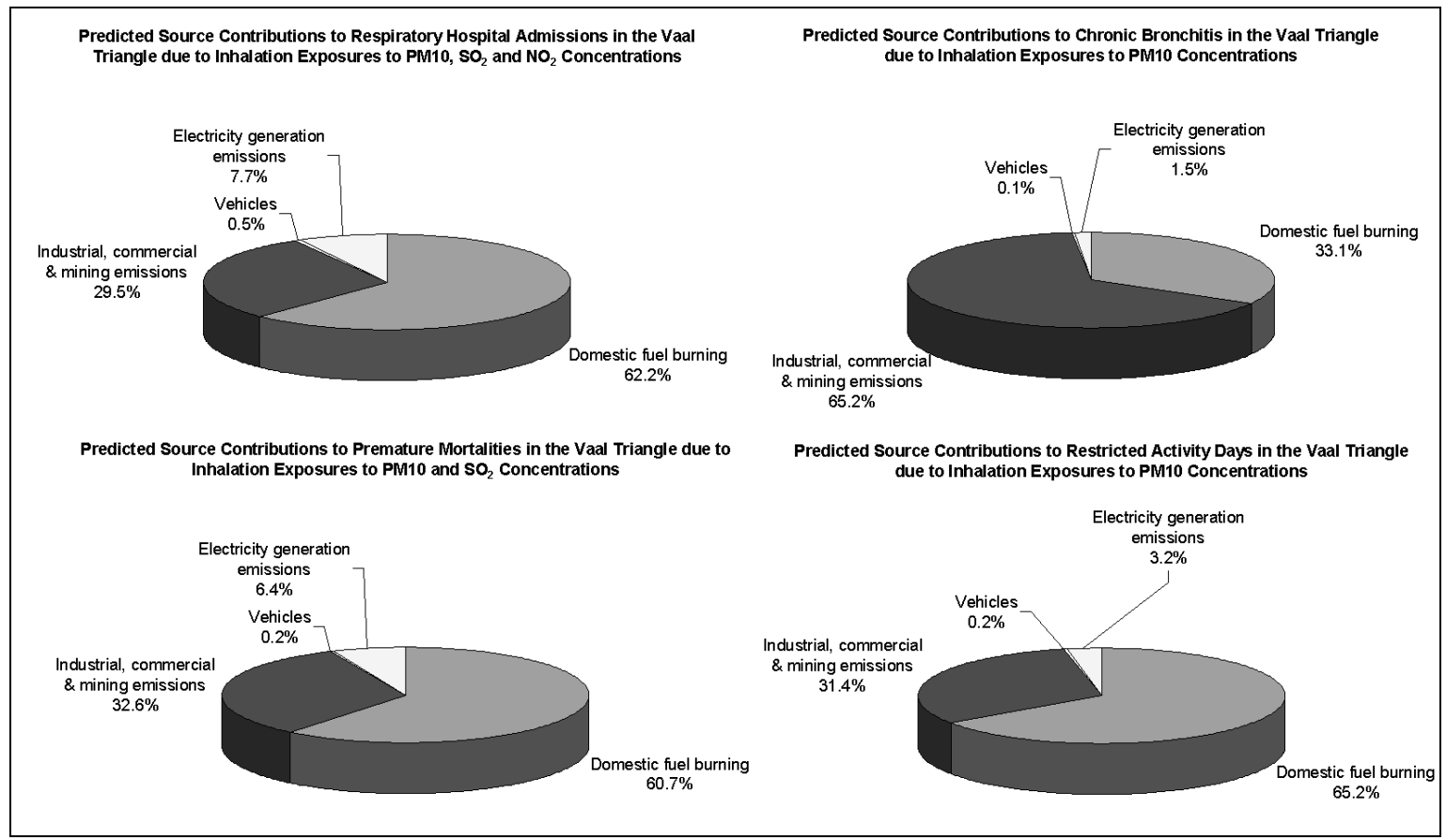

Figure 3. Predicted contribution of source groups to various health endpoints predicted to be associated with human exposures to ambient $\mathrm{PM10}_{2} \mathrm{SO}_{2}$ and $\mathrm{NO}_{2}$ concentrations in the Vaal Triangle.

In a preliminary assessment of the direct costs associated with the predicted incidences of respiratory illnesses reference was made to information obtained from Medscheme. Although the application of doseresponse functions only permitted the calculation of respiratory hospital admissions, the ratio of inpatients to outpatients provided by Medscheme (0.21) made it possible to estimate the number of outpatients likely to be treated. Public health treatment costs were given as comprising $\sim 70 \%$ of the costs of private treatment. The average length of stay given a respiratory hospital admission was given as being in the order of 8.8 days. Average public costs per inpatient were estimated to be R16 618.35 (compared to private costs of R23 740.50). Public costs per outpatient were given as R1 353.69 (compared to equivalent private costs of R1 933.85). Approximately $21 \%$ of the population, based on national figures, was likely to receive treatment from the private health care sector with the remainder receiving treatments from public hospitals and clinics. 
Based on the preliminary health risk cost calculations it is estimated that the direct health costs associated with inhalation exposures to ambient PM10, $\mathrm{SO}_{2}$ and $\mathrm{NO}_{\mathrm{x}}$ concentrations in the Vaal Triangle is in the order of R289 million (Table 5). This costs does not include costs related to other air pollutant exposures and health impacts (e.g. leukaemia cases due to benzene exposures), nor does it include indirect costs due to productivity losses, and as such is considered to underestimate actual costs associated with air pollution exposures. The cost estimate does however provide an initial basis for assessing the potential which exists for offsetting the costs of implementing interventions aimed at reducing air pollutant concentrations.

Table 5 Financial costs (2002 rands) arising due to predicted respiratory hospital admissions and inferred respiratory outpatient treatments due to inhalation exposures to ambient $\mathrm{PM10}, \mathrm{SO}_{2}$ and $\mathrm{NO}_{\mathrm{x}}$ exposures in the Vaal Triangle

\begin{tabular}{|c|c|c|c|c|c|}
\hline $\begin{array}{c}\text { Respiratory } \\
\text { Hospital } \\
\text { Admissions } \\
\text { (inpatients) }\end{array}$ & $\begin{array}{c}\text { Number of } \\
\text { Private } \\
\text { Inpatients }\end{array}$ & $\begin{array}{c}\text { Number of } \\
\text { Public } \\
\text { Inpatients }\end{array}$ & $\begin{array}{c}\text { Cost of Private } \\
\text { Inpatients }\end{array}$ & $\begin{array}{c}\text { Cost of Public } \\
\text { Inpatients }\end{array}$ & $\begin{array}{c}\text { Total Cost of } \\
\text { Inpatients }\end{array}$ \\
\hline 11596.1 & 2,029 & 9,567 & $48,177,160$ & $158,984,628$ & $207,161,788$ \\
\hline $\begin{array}{c}\text { Respiratory } \\
\text { outpatients }\end{array}$ & $\begin{array}{c}\text { Number of } \\
\text { Private } \\
\text { Outpatients }\end{array}$ & $\begin{array}{c}\text { Number of } \\
\text { Public } \\
\text { Outpatients }\end{array}$ & $\begin{array}{c}\text { Cost of Private } \\
\text { Outpatients - } \\
\text { medicines only }\end{array}$ & $\begin{array}{c}\text { Cost of Public } \\
\text { Outpatients - } \\
\text { medicines only }\end{array}$ & $\begin{array}{c}\text { Total Cost of } \\
\text { Outpatients }\end{array}$ \\
\hline 56,434 & \multicolumn{7}{|c|}{9,876} & 46,558 & $19,098,628$ & $63,025,471$ & $82,124,099$ \\
\hline TOTAL COST OF RESPIRATORY CONDITIONS (Rand) & $289,285,887$ \\
\hline
\end{tabular}

\section{IDENTIFICATION OF EMISSION REDUCTION OPPORTUNITIES}

Health risk reductions and associated costs savings are currently being quantified for various interventions as part of the NEDLAC 'Dirty Fuels' project (Scorgie et al., 2003b). In the selection of suitable interventions to evaluate during this project attention was paid to the following: (i) interventions implementable in the shortto medium-term, i.e. within the next $\sim 10$ years; (ii) technological-feasibility; and (iii) interventions already being implemented or proposed for implementation. In the case of interventions implementable within large individual industries attention was paid to already proposed projects with the purpose of determining whether the costs of such projects could be offset by reductions in health spending.

Interventions selected for consideration by the NEDLAC study include the following:

\begin{tabular}{|l|l|}
\hline $\begin{array}{l}\text { Household } \\
\text { fuel burning }\end{array}$ & $\begin{array}{l}\text { Top down ignition (Basa Magogo) } \\
\text { Low smoke fuels } \\
\text { Electrification } \\
\text { Housing insulation } \\
\text { Stove maintenance and replacement }\end{array}$ \\
\hline $\begin{array}{l}\text { Power } \\
\text { generation }\end{array}$ & $\begin{array}{l}\text { Desulphurisation of flue gas } \\
\text { Renewable energy implementation for } \\
\text { allocated energy block }\end{array}$ \\
\hline
\end{tabular}

\begin{tabular}{|l|l|}
\hline $\begin{array}{l}\text { Industrial, } \\
\text { commercial \& }\end{array}$ & $\begin{array}{l}\text { Emission reduction requirements for } \\
\text { coal-fired boilers } \\
\text { Iscor coke oven cleaning project } \\
\text { Sasol natural gas project }\end{array}$ \\
\hline $\begin{array}{l}\text { Vehicle } \\
\text { emissions }\end{array}$ & $\begin{array}{l}\text { Changes in fuel specifications (lead } \\
\text { phase out; reductions in sulphur, } \\
\text { benzene, aromatic content) } \\
\text { Application of EURO standards to new } \\
\text { vehicles } \\
\text { Conversion of petrol vehicles to LPG }\end{array}$ \\
\hline
\end{tabular}

Given that the NEDLAC study is quantifying health risk reductions and associated savings due to interventions on a conurbation-by-conurbation basis, it will provide specific guidance with regard to cost effective solutions which can be implemented within the Vaal Triangle.

\section{CONCLUSIONS RECOMMENDATIONS}

AND

Air pollution concentrations are predicted to result in significant health impacts and associated costs in the Vaal Triangle, with direct health costs associated with respiratory hospital admissions due to $\mathrm{PM} 10, \mathrm{SO}_{2}$ and $\mathrm{NO}_{2}$ exposures estimated at R289 million per annum. Whereas the industrial, mining and institutional fuel burning source grouping is estimated to contribute over $90 \%$ of the $\mathrm{PM} 10, \mathrm{SO}_{2}$ and $\mathrm{NO}_{\mathrm{x}}$ emissions, domestic fuel burning emissions are predicted to be responsible for $60 \%$ to $65 \%$ of the health effects associated with 
acute exposures to these pollutants. Such health effects included respiratory hospital admissions, premature mortality and restricted activity days. The impact of domestic fuel burning emissions is enhanced due to the low level of release, the coincidence of peak emissions with poor atmospheric dispersion potentials, and the occurrence of emissions within densely populated areas with both indoor and outdoor exposures occurring.

Due to the persistence of industrial, mining and industrial fuel burning emissions these sources were estimated to be accountable for $65 \%$ of the predicted chronic bronchitis cases arising as a result of longerterm exposures to PM10 concentrations. These sources were also predicted to account for $\sim 30 \%$ of the estimated respiratory hospital admissions, premature mortality cases and restricted activity days.

Based on the source contribution findings it is evident that interventions which target domestic fuel combustion are likely to be associated with the most significant reductions in respiratory hospital admissions and premature mortality. The implementation of emission reduction opportunities within the industrial and power generation sectors also hold the potential for significant health impact reductions. The cost of implementing interventions aimed at reducing emissions can potentially be offset by the health risk reductions and related financial savings achievable. The application of a damage-function approach as a means of costing health risks associated with inhalation exposures was demonstrated in this paper. This approach provides the basis for assessing source contributions to health risks rather than simply to total emissions. As such it serves as a means of implementing the polluter pays principle in a fair and equitable manner and assists in the identification of the most effective means of reducing exposures.

Improvements to the health risk estimates made can be achieved through the updating and validation of the Vaal Triangle emissions inventory, and through the consideration of other pollutants known to result in health risks in the region, specifically ozone and benzene.

\section{ACKNOWLEDGEMENTS}

Legal Resource Centre is acknowledged for their contribution to air quality baseline assessment studies in the Vaal Triangle. Sasol Chemical Industries is thanked for making available information from their ambient air quality monitoring network for the purpose of informing studies on the region. The contribution of Bently West
Management Consultants to the costing of health risk is appreciated.

\section{REFERENCES}

Abbey DE, Hwang BL, Burchette RJ, Vancuren T and Mills PK, 1995: Estimated long-term ambient concentrations of PM10 and development of respiratory symptoms in a non-smoking population, Arch. Of Environmental Health, 50, 139-152.

Andreae MO, Atlas E, Cachier H, Cofer WR, Harris GW, Helas G, Koppman R, Lacaux J and Ward DE, 1996: Trace gas and aerosol emissions from savanna fires, J.S. Levine (ed.), Biomass Burning and Global Change, MIT Press, Cambridge, 278-294.

Annegarn HJ and Grant MR, 1999: Direct Source Apportionment of Particulate Pollution within a Township, Final Report submitted to the Department of Minerals and Energy, Low Smoke Coal Programme, 10 July 1999.

Britton MST, 1998: Low-smoke Fuel Programme: Laboratory Technical Tests, Determination of Emission Factors, Department of Minerals and Energy, Report No. ES9606, July 1998.

Dockery DW and Pope CA, 1994: Acute Respiratory Effects of Particulate Air Pollution, Annual Review of Public Health, 15, 107 - 132.

Dockery DWCA, Pope X, Xiping J, Spengler J, Ware MF, Ferris B and Speizer F, 1993: An Association between Air Pollution and Mortality in Six US Cities., New England Journal of Medicine 329(24), 1753-59.

EPA, 1986: Air Pollution: Improvements Needed in Developing and Managing EPA's Air Quality Models, GAO/RCED-86-94, B-220184, General Accounting Office, Washington, DC.

EPA, 1995: Users Guide for the Industrial Source Complex (ISC3) Dispersion Models., EPA-454/B-95$003 a$, US-Environmental Protection Agency, Research Triangle Park, North Carolina

EPA, 2000: Compilation of Air Pollution Emission Factors (AP-42), as contained in the AirCHIEF (AIR Clearinghouse for Inventories and Emission Factors) Data Base, US Environmental Protection Agency, Research Triangle Park, North Carolina.

Holland M and Watkiss P, 2002: BeTa - Benefits Table database: Estimates of the marginal external costs of 
air pollution in Europe, Created for European Commission DG Environment by netcen.

Maddison D, 1997: A Meta-analysis of Air Pollution Epidemiological Studies, Centre for Social and Economic Research on the Global Environment, London, University College London and University of East Anglia.

Nelson CD, 2000: The Public Health Impacts of Particulate Emissions from Coal-fired Power Plants in Minnesota, Thesis submitted to the Faculty of the Graduate School of the University of Minnesota in fulfilment of MSc requirement, October 2000.

Ostro B, 1994: Estimating the Health Effects of Air Pollution: A Method with an Application to Jakarta, Policy Research Working Paper 1301, World Bank Policy Research Department, Washington DC.

Qase N, Lloyd PJD and van Zyl H, 2000: Intervention Potential for Low-smoke Fuels in the Coal Distribution Chain, Draft Final Report, Energy \& Development Research Centre, University of Cape Town, 31 October 2000.

Rogers D E C, 1995: Particulate and gaseous emissions from a low-smoke stove using three low-smoke fuels and one domestic coal, Journal of Energy in Southern Africa, May 1995, p 87 - 92.

Rogers DE and Pieters C, 1994: Laboratory tests on emissions from low smoke fuels, Draft report prepared for the Department of Minerals and Energy, Pretoria.

Scorgie Y, 2003: Air Quality Situation Assessment for the Vaal Triangle, Draft Final, Report compiled on behalf of the Legal Resource Centre, Report no. MTX/02/LRC-07a, April 2003.

Scorgie Y, Burger LW and Annegarn HJ, 2003a: SocioEconomic Impact of Air Pollution Reduction Measures - Task 2: Establishment of Source Inventories, and Task 3: Identification and Prioritisation of Technology Options, Report compiled on behalf of NEDLAC, 25 June 2003.

Scorgie Y, Burger LW and Annegarn HJ, 2003b: SocioEconomic Impact of Air Pollution Reduction Measures - Task 4: Quantification of Environmental Benefits Associated with Fuel Use Interventions, Report compiled on behalf of NEDLAC, 30 September 2003.
Stone A, 2000): South African Vehicle Emissions Project: Phase II, Final Report: Diesel Engines, February 2000.

Terblanche P, 1995: Motor Vehicle Emissions Policy Development: Phase 1, Department of Minerals and Energy, Report No. EV9404, June 1995.

Terblanche P, Danford IR and Pols AS, 1995: Comparative Evaluation of Human Exposures to Air Pollution from Low-Smoke and Conventional Household Coal Usage, Journal of Energy in Southern Africa, August 1995, 131-136.

Van Nierop PG, 1995: An Emission Inventory of Particulate Air Pollution in the Vaal Triangle, MSc Dissertation, Faculty of Engineering, University of the Witwatersrand.

von Horen C, 1996: The Cost of Power: Externalities in South Africa's Energy Sector, Energy \& Development Research Centre, University of Cape Town.

Wong CT, 1999: Vehicle Emission Project (Phase II) Final Report, Department of Minerals and Energy, February 1999.

World Bank Group, 1998: The Effects of Pollution on Health: The Economic Toll, Pollution Prevention and Abatement Handbook. 